\title{
Law and the sources of morality
}

\author{
Robert A. Hinde \\ St Fohn's College, University of Cambridge, St Fohn's Street, Cambridge CB2 1TP, UK(rah15@cam.ac.uk)
}

This paper argues that morality is a product of basic human psychological characteristics shaped over prehistorical and historical time by diachronic dialectical transactions between what individuals do and what they are supposed to do in the culture in which they live. Some principles are pancultural: individuals are motivated to look after their own interests, to be cooperative and kind to other group members and to look after their children. The moral precepts of every society are based on these principles, but may differ according to the vicissitudes that the society has experienced. Thus the basic principles can be seen as absolute; the precepts based on them may be specific to particular societies. Moral precepts, and the laws derived from them, are mostly such as to maintain the cohesion of the society, but some have been formulated to further the interests of those in power.

The evidence suggests that laws have been developed, by common consent or by rulers, from generally accepted moral intuitions. In general, legal systems have been formulated to deal with the more extreme infringements of moral codes. Morality prescribes how people should behave; the law is concerned with how they should not. New laws, if not imposed by force, must generally be in tune with public conceptions of morality.

Keywords: law and morality; evolution of morality; development of morality; absolute principles versus culture-specific precepts; cross-cultural communication

\section{INTRODUCTION}

The relations between law and morality have been clouded by differences of opinion concerning the extent to which both law and morality are to be seen as fixed and immutable, or as labile. With respect to law, the distinction between sacred and secular, second nature in the Western world, is simply inappropriate in many societies. Even early in the second millennium BCE all imperatives of life received their value from the fact that they represented the will of the gods as conveyed by the ruler, who claimed to be accomplishing divine wishes (Bottéro 1992). And in the modern world, 'the law' is often seen as given, as what is on the statute book (e.g. Hart 1994). That leads to the view that, in considering particular cases, there should be no relation between law and morality or that, if there is, it is better for lawyers to hold to precedent and disregard it.

Nevertheless, legal theorists discuss such questions as the relative merits of principles of equality, equity, need and justice, and whether penalties are justified by principles of retribution or deterrence: morality is always there in the background (Devlin 1965; Finnis 1980; Freeman 2001). Dworkin (1973) argues that law implies principles of justice and fairness, which can be applied in judicial decisions (see Himma 2003). Furthermore, when new law becomes necessary, as when issues such as in vitro fertilization, genetic modification or abortion are in dispute, moral issues as purveyed by public opinion must be taken into account. Public opinion on such issues clearly has some relation to publicly accepted morality (Warnock 1998):

One contribution of 16 to a Theme Issue 'Law and the brain'. indeed, in a democratic country, laws seen as unjust will not be respected.

In the same way, some see morality as God-given, or at least as absolute. They claim that people know what is right 'intuitively', and that science can have nothing to say on the matter. Others see morality as situation specific, differing between societies and changing with time.

While in the case of law the arguments have been well rehearsed, it is only recently that a scientific approach has been brought to bear on the nature of morality. There are ultimately only three possibilities: either our moral codes are God-given, they have been handed down by 'culture', or they have somehow been derived from human nature. I shall not consider the first possibility, except to suggest that, if moral codes have been derived from human nature, the suggestion that they are God-given is unnecessary. ${ }^{1}$ The second possibility raises the question of where culture, including moral systems, comes from, and leads on to the third, that moral codes are ultimately derived from human nature.

This paper takes the view, based in biology, psychology and anthropology, that morality is a product of certain basic pan-cultural characteristics of human beings, but has been shaped over prehistorical and historical time by diachronic dialectical transactions between individuals and the culture in which they live. That is, throughout human history, the behaviour, values and attitudes of individuals have continuously influenced and been influenced by the culture in which they live. Moral principles are based in human nature, but societies and their cultures change, leading to a limited differentiation of moral codes between societies. Thus morality is neither absolute nor wholly socially constructed. 
(See Arenhart (1998) for a similar view reached from a somewhat different perspective.)

What does it mean to say that moral codes and values are derived from human nature? Certainly not that they are encoded in our genes, for all adult characteristics depend ultimately on both genes and environment. Nor, given the basic cross-cultural similarity between moral codes, is it likely that they are merely the 'brainchildren' of enlightened individuals. Rather, from pancultural bases moral codes have differentiated over time, largely through mutual influences between what individuals in the society do and what they are supposed to do. That interaction has depended on the vicissitudes to which the society and the individuals within it have been exposed, and has been directed mostly towards fostering smooth social relations between individuals. Thus moral codes are not rigid, but differ to some extent between societies and may change gradually over time. However, they are not infinitely flexible: the moral precepts in every society are related to a few pancultural principles. All humans have a tendency to be assertive and look after their own interests, and all have propensities to behave prosocially to kin and to other group members. The hypothesis advanced here is that moral precepts are such as to swing the balance towards prosociality so that group living is possible, though that does not mean that all so-called moral precepts facilitate group living. It is also suggested that legal systems, far from being independent of moral codes, are in large measure such as to deal with extreme infringements of moral codes.

The first section of this paper, therefore, highlights briefly the continuous interplay between biological and cultural influences in the development of morality in the individual and in the emergence and historical development of morality. It is followed by a suggestion that moral and legal systems share common roots. The final section considers the relations between law and morality: first the relevance of the current approach to situations where the legal system of one country is unacceptable to the moral code of another, and second the similarities and differences between morality and English law.

\section{THE INTERPLAY BETWEEN BIOLOGICAL AND CULTURAL INFLUENCES}

(a) The development of morality in the individual

The doctrine of original sin suggests that children are born evil. However, much of the behaviour that is undesirable to parents is part of natural development and/or the result of the artificial conditions of modern life. Children take delight in 'testing limits', but that is part of learning how far they can control their own environments, how far their assertiveness will take them. Equally, by 1 year of age children show behaviours that could be considered as morally good-sharing, care-taking, taking turns, sympathy, etc. (Rheingold \& Hay 1980). This, of course, does not indicate a fully fledged moral capacity, and must be regarded as 'proto-moral'. Thus, young children are predisposed to develop behaviour that we consider as moral, as well as to assert themselves.

Children are also predisposed to please their parents or other adult caregivers. They like to help, to obey and imitate their parents, and they look warily at their parent if they violate a sanctioned act (Eisenberg \& Fabes 1998).
Biologically, this is not surprising: young primates depend on parental proximity and on obedience to parental signals for their survival. However, children are predisposed to acquire both moral (prosocial ${ }^{2}$ ) and immoral (selfishly assertive $\mathrm{e}^{3}$ ) behaviour: parental treatment, depending on its nature and quality, may augment either.

The development of moral behaviour and so-called 'moral intuition' depends on numerous aspects of psychological functioning as well as on relationships with caregivers, and it is unnecessary to review its course here. The important point is that children have propensities for both prosocial and selfishly assertive behaviour, and the relative strengths that these acquire depends on their relationships with others.

In the early phase, interactions with family members are crucial: later the peer group, authority figures, cultural idols, etc., also exert their influence, but early experience is of special importance. Prosociality is most likely to be engendered by parents who are sensitive, loving, but exert reasoned control (Bowlby 1984). Parents, in turn, are influenced by their own circumstances: if the world is harsh and competitive, it is more difficult for them to be sensitive. And if the prevailing culture emphasizes assertive masculinity, they are likely to encourage this in their male children.

The internalization of moral precepts can be conceptualized in terms of the 'self-system'. Everyone acquires, primarily through observing how others behave toward them, a view of their own characteristics. Thus, one may see oneself as white Caucasian, female, a law graduate, sensitive, hard-headed, and a member of the Middle Temple with strict moral values. Data show that one tries to maintain congruency between how one perceives oneself (one's self-concept), how one sees oneself to be behaving and how one perceives others to perceive oneself (Backman 1988). Thus, if one perceives oneself as honest and to be behaving honestly, but perceives others to see oneself as deceptive, congruency must be restored. This may be achieved by trying to convince others of one's honesty, or by 'cognitive restructuring', that is by misperceiving what others say, devaluing their opinion or listening selectively to the one voice that confirms one's honesty. This provides us with a way of conceptualizing the conscience. How one sees oneself includes the nature of one's relationships with others and the rules (including moral precepts) that guide those relationships. If one sees one's behaviour as incompatible with the internalized moral rules, one experiences emotion (e.g. guilt) and may act to restore congruency. If, however, one sees oneself as behaving consistently with the moral rules one feels the pleasure of virtue.

The moral precepts that individuals acquire are best considered according to the aspect of social life with which they are concerned.

\section{(b) Moral precepts with those perceived as kin}

Certain aspects of morality can be safely ascribed to pancultural psychological characteristics that are the product of natural selection. (This of course does not mean that they are 'innate' and develop autonomously: they may depend on experiences common to all humans.) Most obvious here are aspects of the relationships between parents and their children and between others who see themselves as related. It is not only 'natural' for parents to 
love their children and children their parents, but it is considered morally right that they should do so. Prosociality between parents and their offspring is ubiquitous among mammals. Since natural selection acts to promote the survival of genes, this can reasonably be ascribed to natural selection, for the child shares half its (rare) genes with each parent. Theory predicts that prosociality with more distantly related individuals would be reduced according to the degree of relatedness (i.e. the proportion of their genes that they share): this is confirmed by data on both human and non-human species (Hamilton 1964: Betzig et al. 1988). Thus, varying between cultures, one has some moral obligation to act prosocially to aunts and cousins, but less than to behave prosocially to children, parents or siblings.

Interestingly, the Hebraic Commandments enjoin children to honour their parents, but not the reverse. Presumably parental love was assumed, or the Commandments were written from the parental perspective. We shall encounter other instances of moral rules prescribed with self-interest later.

The degree to which parents are expected to support their children decreases with their age. We say, 'They ought to be independent by now'. This is also in accordance with evolutionary theory. It is in the evolutionary interests of parents to look after their children only for so long as it does not overly diminish their own prospects for further reproduction. As children develop, they demand more parental resources until they demand more than the parent is prepared to give. This same biological principle also accounts for other common phenomena-for example, the difficulties that arise when a sibling is born and the care lavished on a last-born (Trivers 1974).

Certain apparent exceptions must be noted.

(i) Contraception reduces an individual's reproductive success. However, in pre-industrial societies it balances the welfare and reproductive potential of children already born against the negative effects that an immediate further conception would have on lifetime parental reproductive success. In the industrial world the use of contraception has been increased by the desire of parents for satisfactions other than those inherent in parenthood.

(ii) Infanticide has been used as a method for controlling family size, and by women who are undernourished or severely disadvantaged, who fear ostracism following the birth of an illegitimate child, or who have borne a severely congenitally abnormal child. In such cases the child would be unlikely to contribute to the parent's long-term reproductive success. In western societies step-parents, who are not biologically related to the children, are much more likely to kill or abuse children than natural parents (Daly \& Wilson 1996; Jones 1997; Hrdy 1999).

(iii) Adoption. In pre-industrial societies this is usually by relatives of the parents (Silk 1980). In industrial societies its prevalence must be attributed to the desire for parenthood experienced by many adults.

Thus, many exceptions to the general rule that individuals attempt to maximize their long-term reproductive success can be understood. Such exceptions are often codified by custom. Others result from cultural desiderata other than parenthood.

\section{(c) Relations with non-kin}

Considerable insight into the dynamics of personal relationships comes from the view that relationships involve processes of exchange, individuals incurring costs (in an everyday sense) in the expectation of future rewards (e.g. Thibaut \& Kelley 1959; Kelley 1979). Originally applied to marketplace transactions, exchange theories have been applied also to close personal relationships. (This does not imply that reciprocal exchange is all there is to close relationships.)

Certain consequences of this are important here. Continuity of interaction between two individuals depends on the satisfaction of both, and the rewards for a given act may lie in the future: A behaves well towards B in the expectation that B will later behave well towards him. Thus, to maintain the relationship, each participant must maximize not only his own outcomes but also those of the partner. If A does not consider B's outcomes as well as his/her own, B may opt out of the relationship and A would lose any expected return. Furthermore, initial interactions should be positive, for otherwise the other individual may refuse further interaction; trust that the partner will reciprocate, together with belief in the partner's commitment to the relationship, are essential for continuity. Therefore valuing prosociality, reciprocity, trust and commitment to the relationship follows immediately from the principle of exchange.

In the long term, the rewards exchanged must be seen as fair. What matters are not the resources actually exchanged, but those perceived as having been exchanged. Criteria of what is fair vary with the nature and age of the participants, circumstances, etc.; but always what matters is the perception of fairness. In some circumstances individuals do not seek to maximize their own rewards, but dislike situations in which they consider themselves to be over-benefited, feeling embarrassed or guilty (Prins et al. 1993). This implies that individuals are guided, perhaps unconsciously, by a contract demanding justice in personal relationships.

If reciprocity is delayed, gratitude may be accepted as an appropriate return, at least temporarily indicating that one has not incurred costs without expectation of future returns. All this occurs against a background of the moral precepts and values in one's self-system. We see individuals who express gratitude as 'polite', and value politeness.

Perception of the infringement of reciprocity requires that congruency be restored (see $\S 2 \mathrm{a}$ ): if met with ingratitude, one may denigrate the recipient of one's own prosocial act. Or, if one has acted unfairly oneself, one may attempt compensation, or distort one's own view of the other individual or his outcomes.

In a large group, an individual may never meet again the recipient of his prosocial action. However, the latter may express publicly his gratitude, or the prosocial act may be witnessed by others: the prosocial individual then gains a reputation for prosociality, and this will make other individuals more willing to deal with him/her in the future. Thus a reputation for generosity, or for prosociality and reciprocity, is valued (Alexander 1979; Hawkes et al. 2001). 
Exchange theories were elaborated to explain how people behave, not how they ought to behave. But there are close parallels between exchange theories and moral codes and values. A principle of prosociality/reciprocity is preeminent in probably all societies, and a version of the Golden Rule of do-as-you-would-be-done-by is basic to all moral codes (Küng \& Kuschel 1993). Some of the Ten Commandments, such as those about killing, adultery, stealing, false witness and coveting, are admonitions not to do things that one would not like to have done to oneself. Just reciprocity and prosociality are fundamental to the functioning of human groups. It is morally correct to act prosocially and to promote the welfare of others. Many recognized virtues depend on prosociality/reciprocity, for instance honesty, trustworthiness, generosity, commitment and sensitivity to others' needs.

How could one account for the ubiquity of some form of the Golden Rule across human societies and successive generations? Social groups could not be stable if individuals were predominantly selfishly assertive, but at first sight this presents a problem for evolutionary theory. Natural selection involves some individuals leaving more offspring in the next generation than others. Selfishly assertive individuals, looking after their own interests, might be expected to be more reproductively successful than prosocial ones: if so, successive generations would become progressively more assertive.

However, modelling techniques show that cultural selection for prosociality is possible if competition and selection both between individuals within groups and also between groups is considered. Although genetic evolution by selection between groups is at best extremely rare, the critical issue may be not that the differences between individuals should be genetic, but that they should be passed on from one individual to another by some means or other. The question then becomes, could culturally maintained similarities between individuals within a group and culturally maintained differences between groups provide a basis for group selection? Computer modelling shows that prosocial behaviour could be favoured by competition between groups under certain conditions-namely if naive individuals were to copy the behaviour most common in the group (conformism), the environments in which groups lived were heterogeneous, and groups moved from time to time. Conformism is a ubiquitous human characteristic, and the other conditions are likely to have held earlier in human history (Boyd \& Richerson 1991, 1992; Sober \& Wilson 1998; Wilson \& Kniffen 1999). Competition between groups could have involved relative success in obtaining necessities, not necessarily actual warfare. It probably acted both at the group level, some groups being more successful than others, and at the individual level, individuals living in successful groups being more successful in spite of the costs that their prosociality incurs.

The evidence thus favours the view that prosocial behaviour and reciprocity evolved through processes of selection. The tendency to show prosocial behaviour to a related other, discussed in the previous section, implies helping another who is genetically related and therefore similarly likely to be helpful to relatives. Here, we see that prosociality to an unrelated other could be selected for if the other were likely to reciprocate. In practice, each of these processes carries some of the benefits of the other. Helping a relative is helping another who is likely to help others, including the original helper. Helping an unrelated other who is likely to reciprocate means helping another who is also inclined to help others, including the original helper (Humphrey 1997).

That propensities to behave prosocially and with reciprocity are part of human nature is supported by the ubiquity of many human characteristics that support exchange. We have an acute sense of justice, are good at detecting cheating (Cosmides \& Tooby 1992) and feel moral outrage when we see someone else cheating. One feels anger if unfairly treated, guilt or shame when one knows oneself to have behaved improperly (Tangney 1995). We respect honesty, fidelity, trustworthiness and commitment-virtues that are encapsulated in the concept of friendship (Frank 1988). We go to some lengths to convince others that we have these virtues. The exercise of these virtues can bring its own rewards in the shape of selfesteem and an enhanced reputation that will in turn induce others to behave positively towards oneself (Hawkes et al. 2001). Societies also have conventions and laws about fairdealing that support reciprocity.

Thus, diverse aspects of human behaviour support the display of prosocial behaviour and reciprocity with ingroup members. This does not mean that experience plays no part in their development in individuals. We have seen that the balance between prosociality and selfish assertiveness is influenced by experience, and there may be circumstances where unbridled selfishness pays off (De Vries 1984).

But it must not be thought that what is natural is to be seen as right, or that what is right is natural. The point is that how people actually behave, as studied by social psychologists, has many parallels with how people should behave, and that both are supported by psychological characteristics that are probably pancultural and likely to have been the product of natural selection. The principle of reciprocity is reified as a general principle and can be used to support moral precepts-'Do not hit Johnny: you would not like it if he hit you'.

The Golden Rule applied to those seen as in-group members is probably common to all cultures. However, that does not mean that all values related to it are pancultural. People in different societies have interpreted it in different ways.

\section{(d) Status and rights}

(i) Status

We have seen that, in addition to a propensity for prosociality, human infants also have a propensity to act with selfish assertiveness. Children attempt to assert their own authority. This propensity, just like that for prosociality, is affected by experience. A young man brought up in gangland in a large city is likely to take a pride in selfish assertiveness rather than prosociality.

In virtually all societies the assertiveness of individuals has led to status hierarchies. The criteria for high status differ between societies-physical strength, wealth, wisdom, beauty, gender, generosity, humility and many other qualities are valued in different societies and different contexts. The characteristic that leads to high status is either beneficial to the group (e.g. courage, generosity), or linked 
to envy (access to resources, women, etc.) or is a desire to possess (beauty in the opposite sex).

Status not only brings access to resources, but is also sought independently of any immediate access to resources that it may bring. High-status individuals seek to maintain the status quo, either because they believe it to be in the general interest or for their own purposes, whereas those low in status may seek to change it. Those in power do best if they can avoid force and use persuasion or guile to convince others that the status quo is in their own interests. Highstatus individuals may assume divine support or emphasize the moral rectitude of loyalty. And they may promote humility as a virtue, leading to reward in a later life: the Anglican catechism requires the confirmand to promise to honour the ruler and all in authority under him, and to 'order myself lowly and reverently to all my betters'.

Acceptance of low status may be facilitated by the realization that it is a good strategy: they are alright if they do not make a nuisance of themselves. Furthermore, it may become a matter of exchange, the low-status individuals profiting from the protection or benevolence of their superiors. Thus the maintenance of status differences, though resulting from assertiveness, may not be merely a matter of immediate pressure from those at the top.

\section{(ii) Rights}

Another way in which self-assertiveness is related to moral issues concerns the demand for individual autonomy and rights. Self-assertiveness is closely related to the development of selfhood and a sense of agency. Individuals strive to control their own environment and fate. Often this takes the form of seeking protection from control by those of higher status (such as parents) over actions that they consider to be outside justifiable regulation by others. Doing one's own thing, maintaining one's integrity, become matters of overriding concern. In many societies freedom of opinion, speech, movement and so on are regarded as 'inalienable'.

In practice rights are not quite 'inalienable', and differ to some extent between cultures. Limits may be set on the individuals to whom they apply: women and mentally handicapped individuals may be seen as having fewer rights than men, criminals to have no freedom of movement, enemies of the state to have no right to life. Even the socalled 'inalienable' rights are seen to have limits: freedom of expression may be seen as a universal right, but should not include the right to broadcast how to make chemical weapons. The right to autonomy is seen early in development but limits are set by cultural convention or law.

\section{(e) Moral precepts concerned with sex and gender}

The ways in which people behave and how they are supposed to behave in matters concerning the relations between the sexes are complex and diverse. Every culture has norms, some elevated to the status of moral precepts and/or secular laws, regulating sexual relations, and in none is total promiscuity allowed. For that reason, and because the socio-sexual systems of animals are equally diverse, direct comparisons with animals are extremely dubious. However, principles about the evolution of behaviour sometimes mesh surprisingly well with what we know about human behaviour.
Some societies are monogamous, some polygynous, a few polyandrous. In some a woman may profit from having intercourse with several partners because she may obtain better genes for her children, or because she thereby acquires their subsequent help in rearing her offspring (Hill \& Hurtado 1996). In others biological parents do not live together, the parental role being taken by the mother's brothers (Hsu 1998). The diversity is enormous but in every culture moral codes have been elaborated to ensure that unbridled sexuality will not disrupt the social system and/or to safeguard the sexual interests of the more powerful individuals. However, invariably there is a gap between how people ought to behave and how they actually do.

Some ubiquitous characteristics of socio-sexual relations show parallels between the reproductive requirements of men and women, differences in their psychological characteristics and differences in the expectations and rules governing their sexual behaviour. Natural selection acts through reproductive success, and the reproductive requirements of the sexes differ.

In all mammals the potential lifetime reproductive success of a female is limited by the time necessary for pregnancy and (in many societies) lactation, whereas that of a male is set by the number of females fertilized. Competition between males for mates is therefore stronger than that between females, and the variance of male reproductive success is much greater than that of females. Men must compete for sexual partners and protect those they have acquired. Male aggressiveness and assertiveness, machismo traditions, and protective chivalry towards women are in harmony with this. Cross-cultural data indicate that adjectives such as 'aggressive', 'boastful' and others that could be called anti-social are seen as appropriate to men (Williams \& Best 1982). In harmony with this, in most societies men hold the power in the social and political spheres. Not only do they compete for mates but it is also in the interests of those with power to maintain the status quo and order in the society to protect their wives from other men.

In addition, a woman knows that the child in her womb is her own, but a man can be cuckolded. Thus extramarital mating by a man does not lower the reproductive success of his wife unless it involves diversion of resources to another woman, but extramarital mating by a woman may result in the man expending parental care on children that are not his. In harmony with this, in probably all societies men are allowed more sexual licence than women (though male promiscuity is not necessarily seen as right). Women are expected to be chaste, modest and faithful. The difference is institutionalized with special clarity in the Muslim sphere of the haram, and in the association of male machismo with female virtue in many Catholic societies.

A child tends to be valued more by its mother than its father. The proximate reason for this may lie in feminine dispositions or in the fact that the mother has incurred more costs in rearing it. But this is also in keeping with evolutionary theory: not only may the father have been cuckolded, but also he must expend fewer resources in creating another child than must she. It is thus not surprising that, although men hold political power, in many societies women have the power in the home and control the food stores. 
Again, in so far as earlier in human history, a mother needed the continuing support of a male partner, it might be expected that secure relationships would be more important to women than to men. A number of lines of evidence support this view (Gilligan 1982; Eisenberg \& Fabes 1998). Adjectives such as 'affectionate', 'gentle' and 'kind' are perceived to apply more to women than to men, and empirical data show that relationships are more important to women than to men. In general, men tend to focus on justice (in keeping with their need for control in the political and social spheres), women on nurture and relationships.

Some social rules can be seen as the result of the reification of customs seen to be reproductively successful. Thus social intercourse between spouses is usually required, and some religions forbid contraception. Intercourse during menstruation may be forbidden, but that is likely to increase its frequency during the fertile period. Such practices may be in the reproductive interests of individuals, and this in turn increases the size of the community dominated by the religious specialists who uphold the moral code.

Unfortunately the origins of the cultural differences are usually lost in the mists of time (but see $\S 4$ ). But the parallels between biological predictions and social fact are in keeping with the view that many of the cultural expectations and stereotypes have arisen on the basis of the biological predispositions, and are the result of diachronic twoway interactions between what people do and what they are supposed to do. The basic differences in predispositions between male and female neonates may be small, but they are present and are subsequently accentuated through interactions influenced by the cultural norms. Members of both sexes seek to acquire those characteristics that have brought reproductive success to their predecessors and are now seen as desirable for their gender. Members of both sexes will support norms and expectations concerning the other sex if those norms and expectations favour their own interests. From an ultimate evolutionary point of view it is in men's interests that women should be nurturing and caring, and in women's interests that the men with whom they bond should be successful in competition with other men and be good providers.

Another problem that requires integrating biological and social approaches concerns the ubiquity of incest taboos. Biologists define incest as mating between genetically closely related individuals, and both animal and human data indicate that it is biologically undesirable because of the deleterious effects of too close inbreeding on reproductive success (Grand \& Bittles 1997). Anthropologists and other social scientists, impressed by the diversity of incest taboos and by the fact that the prohibitions often do not concern close genetic relatives, define incest taboos as preventing sexual relations between those whose relationship culturally debars them from having sex with each other. Most cultures do in fact discourage sexual relations between individuals closer than first cousins, in keeping with the biological view. Indeed in many cultures marriage to a member of another group may be required.

However, there are many exceptions. In some groups endogamy is encouraged, perhaps because of the difficulty of finding an unrelated spouse in a small community or because marriage to a close relative facilitates marriage arrangements, eliminates the need for dowry or bridewealth, or ensures that possessions remain within the extended family; but outside, bodies may intervene. In Europe the Christian Church discouraged close marriages, thereby weakening consanguineous ties and increasing the Church's power to obtain bequests.

There is also evidence for a psychological mechanism involving reluctance to mate with an individual who had been familiar in early life (Bevc \& Silverman 2000). Thus again we see a relation between psychological propensities, the reproductive advantages that they bring, and cultural expectations and rules that may be complicated by the history and situation of the society in question.

\section{(f) Social and religious systems}

Although the parallels between psychological propensities, biological functions and moral precepts have been considered separately for several social contexts, these are not independent: the several precepts are more or less integrated in a moral system that serves primarily to maintain group cohesion. For instance, early in human evolution when groups were small, cooperative defence and hunting must have been essential for survival, and family and group loyalties must have been nearly coincident, facilitating group integrity. Sexual prohibitions are (usually) conducive to the smooth running of groups. Selfish assertiveness may be a disruptive factor, but the self-assertiveness of leaders may foster group integrity.

Many psychological mechanisms, presumably pancultural, serve in the cohesion and functioning of groups. Many cultural devices also contribute to group integrity. Social norms and moral precepts, as well as symbols such as national flags, rituals such as parades, and metaphors play a part. The metaphors (such as motherland, brothersin-Christ) can be seen as parasitic on the consequences of kin selection. Denigration of out-group members may also result. Virtues, such as loyalty, public beneficence and courage, are presumably consequences of group living. They may acquire moral status: lack of loyalty may provoke sanctions, including ostracism, and in wartime even more severe penalties.

Group distinctiveness is also maintained by customs and moral precepts promoting differences from other groups. The dietary prohibitions of Leviticus, male circumcision and even monotheism probably contributed to maintain group distinctiveness. These are regarded as moral issues by many religious adherents. Christian missionaries sometimes promoted precepts concerned with secular matters to foster the integrity of a religious community, thereby creating an effectively separate society of converts (James 1988).

Where group integrity is of major importance to secular or religious leaders, the observance of precepts may be elevated to legal status, with heretics being burned and traitors executed. Again, basic human psychological propensities, in this case leading to the maintenance and integrity of groups, are paralleled by moral precepts, and in some extreme circumstances by the law.

\section{SUMMARY OF THE ARGUMENT}

On this view, therefore, there are pancultural propensities to look after one's own interests and to behave prosocially 
to others, especially to kin and also to in-group members. These principles are neither there in our genes, nor are they just given by an outside source. Because resources have seldom been superabundant, natural selection has ensured that individuals are endowed with a tendency to look after their own interests and those of their relatives. Because individuals have fared better as members of groups than by living singly, they also have tendencies to behave prosocially and cooperatively towards individuals perceived as members of their own group. These propensities form a basis for all moral codes.

With these as a basis, the precepts and values guiding the behaviour of individuals are a product of dialectical relations, over prehistorical and historical time, between what individuals do and what they are supposed to do according to the culture or shared understandings of the society in which they live. Morality is neither immutable nor infinitely labile, but constrained by the basic principles of selfish assertiveness and prosociality. The relative preponderance of prosocial and selfishly assertive behaviour shown by an individual will be affected by the social and physical environments that he/she and the society have experienced.

Thus, notwithstanding the view that it is fallacious to derive what ought to be from what is, this approach indicates that a scientific approach can make a major, and perhaps fundamental, contribution to understanding the bases of morality. At the group level, it leads to understanding the prehistorical, historical and current processes that lead to the range of precepts governing behaviour in a society; and at the individual level the role of the genetic constitution, and the environments encountered, on the balance between prosocial and antisocial behaviour that results. At the intra-individual level, studies of neural mechanisms may, in principle, lead to understanding how moral precepts are encapsulated in the brain, the bases of the selfsystem and the nature of the conscience.

Again, this is not saying that what is natural is right. The criteria of survival and reproduction by which natural selection honed the basic pancultural psychological characteristics are not the same as those we use to assess moral codes in the world today. Conventions and values change, and new discoveries demand new precepts. Natural selection has acted to promote lability according to current circumstances, and that can involve selfish assertiveness taking precedence over prosociality in some circumstances. In any case, the extent to which prosociality 'should' predominate over selfish assertiveness depends on the situation. Excessive unselfishness may be seen as wrong because it involves the neglect also of responsibilities, or as embarrassing because one can never repay the debts incurred.

Moral precepts are normally those that favour group integrity and integration. However, the self-assertiveness of powerful individuals may cause them to propagate precepts in their own interests, whether or not those precepts are conducive to group harmony. Since one must presume that individuals in well-integrated groups fared better than those in chaotic or disintegrating ones, prosocial or ingroup cooperative precepts and behaviour must, and do, predominate over self-assertive and socially divisive ones.

\section{THE EMERGENCE OF MORAL AND LEGAL SYSTEMS}

The preceding sections have assumed that certain pancultural characteristics and propensities have resulted from natural selection, and argued that they were one source of moral precepts. However, moral codes (and, as we shall see, legal systems) evolved over prehistorical and historical time. This mostly occurred long before records were available, so only indirect evidence and speculation are available. However, the issue is an important one, for it could illuminate the dynamics of moral and legal systems today. What follows, therefore, is merely a tentative scheme.

Presumably kin selection played a large part in the genesis of early human groups. Selfish assertiveness leading to competition for mates and material resources must have occurred. Nevertheless cooperative prosocial behaviour must have predominated over selfish assertiveness.

Evidence from modern hunter-gatherers, which admittedly may be misleading, suggests that early human groups tended to be egalitarian. This does not mean that status seeking was absent, but rather that individuals acted together to curb attempts at self-aggrandizement. Presumably selfish assertiveness would be seen by others as threatening their own interests.

In the absence of over-arching authority, readiness for revenge would provide the best defence against attack or exploitation. Today, revenge is central in curbing conflict in many non-literate societies (Evans-Pritchard 1940), and can be seen as a facet of the propensity for reciprocity. However, revenge, if not seen as just, can lead to escalation. Although perhaps initially a spontaneous product of selfish assertiveness, it must have been based on shared understandings about what was not acceptable behaviour. In turn, these shared understandings could have been replaced by more or less formalized rules. Perhaps this was the result of conformism: in a successful group, prosocial and cooperative behaviour must have been frequent, and conformism would lead to what most people did being transformed into what they ought to do. Formalization could have been the collective result of the experience of individuals, or the action of a charismatic leader. Collectively recognized rules could have led to punishment for non-compliance, and perhaps to rewards for those who prevented or punished anti-social behaviour. Because individuals who behave prosocially tend to receive prosociality and to be admired, prosociality would bring status and its own rewards.

Nevertheless, environmental vicissitudes must have led to differences in experience, and in the balance of prosociality and selfish assertiveness, between groups. In time, however, leaders emerged-perhaps through physical domination, or perhaps because their advice turned out to be sound. Dissent and competition for power could then have been quelled from above. It would have been in the leader's interests to maintain peace and thus the status quo in the society, and to promulgate rules to that end. They may also have promoted values that were in their own interests, such as the moral rectitude of humility. At an early stage leaders probably claimed divine authority for promulgating rules governing the behaviour of individuals and punishments for those who infringed them (Roth 1995).

However, leaders must be kept from exploiting their positions, and their power must be limited by appropriate 
institutions. Here, reciprocity may operate: for instance the leader may provide protection in return for service and respect.

Some of these processes have been documented in the development of Anglo-Saxon law. The old folk community, collectively bound to peace, came to be held together by the King. What had been folk peace became the King's peace, and offences initially seen as offences against an individual or the community were seen also as offences against the King's peace. Thus authority for retribution, originally belonging to the wronged individual or his kin or the community, became transferred to the King. Punishment involved both retribution to the wronged party (or to relatives) and an element to the King, the latter for the infringement of the folk or King's peace. Initially most offences were punished by outlawry, but later many offences were expiated by a payment, part of which went to the injured party and part to the King (Adams 1896).

However, neither moral systems nor legal systems are static. Perhaps the most important basis for change has been the dialectic between what people do and what they are supposed to do. For instance, a few decades ago divorce was regarded as disreputable in England. For a number of reasons, including the desire of women for more independence after World War II, the incidence of divorce tended to increase. As divorce became more frequent, it became more acceptable. As it became more acceptable, it became more frequent. There were also concomitant changes in the law, induced in part by the perceived consequences of conflict-filled marriages on children.

Finally, the law tends to reflect both the history and the current situation of the society. The history of the Israeli kibbutzim illustrates this. Set up mostly by individuals who had left totalitarian regimes, they presumed initially that goodwill and shared understandings would make laws unnecessary. It soon became evident that this was not enough, and laws were formulated. Each kibbutz had a General Assembly: presumably because conditions were still hard, appropriate punishment was judged not only on the rights and wrongs of the specific act, but also on the nature of the offender as assessed by his/her past contributions to the community (Saltman 1985).

Another example of the influence of the past on current morality is suggested by the differences between Western societies and some Eastern ones, such as the People's Republic of China. It has been argued that European morality is based on the importance of the individual, and stems in part from the Christian belief in individual salvation, with God sending his Son to save individual sinners. Chinese morality stems from the Confucian view of the world, which, although experiencing vicissitudes in the twentieth century, still has an underlying influence. The Earth and the Heavens were seen as constituting an ordered and harmonious system. Harmony in the relatedness of individuals was viewed as the most valuable feature of human existence. Therefore, virtue is still seen not in terms of submission to a deity, but as the building of constructive communities. Not surprisingly, the rights and duties of individuals with respect to the community are seen differently in the two systems (e.g. Huntingdon 1997).

\section{CROSS-CULTURAL PROBLEMS}

Every society has experienced a different history, so inevitably moral precepts and values differ to some extent between societies. Attempts to specify moral codes must be restricted in their scope. What has become conducive to group integrity over historical time in one society may not be so in another. Furthermore, especially in modern times, circumstances are constantly changing; the dialectic between what people do and what they are supposed to do is always in flux, so that the details of moral codes may change. But prosociality must predominate: undiluted selfassertiveness inevitably leads to group disintegration.

Education should lead to greater 'understanding of' (in the sense of sympathy for) the moral precepts of other societies. Where precepts differ, a focus on human commonalities, the universal characteristics and needs of human beings, is the best starting point for the resolution of any conflict. Inevitably, people brought up in one culture, having assimilated its precepts into their self-systems, are unlikely to take easily to any other. And neither the 'missionary' course of trying to convert them by argument to one's own views, nor political pressure on the society, is likely to prove successful. Example must be the best option.

In judging the moral systems of other societies, one tends to judge them against one's own moral standards. What matters to members of another society is, in the first instance, what they perceive to be right. A young woman in another society might perceive it as right that she should marry the husband that her parents choose (though not all do), while we should see it as incompatible with the Golden Rule. The woman is doing what she sees as right, and probably her parents see their choice of spouse as right, though we see it differently.

There are, of course, difficult issues here: no amount of education can bring understanding of some cultural differences. Practices of burning widows, or of deserting the aged, of female genital mutilation, of killing citizens of another race, of killing to uphold family honour, are totally unacceptable to those brought up in Western society. One suspects that such practices were initially introduced by powerful individuals within the society for their own interests or what they perceived to be the interests of the group as a whole. Since they contravene the basic principle of doas-you-would-be-done-by and deny individuals their essential rights as persons, they must be seen as unacceptable (although they may stimulate reflections on some practices in our own society, such as male genital mutilation).

But if one is tempted to make judgements, as one must be in such cases, it is important to judge separately the individual and the system. A concentration camp guard, brought up in a totalitarian state with a genocidal policy, may see it as right that he should carry out his duties. The system is, of course, despicable, but is the guard? Perhaps the key issues are the amount of choice he had and whether he could have known that his actions were wrong. Particular difficulties arise when British judges, to whom the death penalty is abhorrent, must adjudicate over the appeals of condemned individuals in another country.

Circumstances change, and sometimes values and precepts must change with them, but here a strong dose of conservatism is necessary. The moral code of a society has been honed over generations in the circumstances of that society. Values that we place on honesty, trust, 
compassion, responsibility and love have arisen as consequences of what we are and our need to live in a viable society with reliable interpersonal relationships. Major changes in circumstances, or new scientific developments may require innovations in the moral code, but change in our moral system must not be undertaken lightly. We must start with what has served us well so far, and remember that a code that is not acceptable to a high proportion of individuals will not be accepted.

\section{THE NATURE OF MORALITY IN RELATION TO THE LAW}

This final section considers how this view of the genesis of morality bears on its relations to law, with the focus primarily on English law.

First, certain questions about morality that have occupied legal theorists turn out to be non-questions. For instance:

Are values arbitrary? Some are, some are not.

Is morality fundamental or constructed? A bit of both.

Is morality subjective or objective? It can be described objectively but is felt subjectively.

The preceding sections indicate that law and morality had a common source and that there have been parallels between their respective developments. Both are concerned with social order, and their development involves social processes. Many laws are formalizations of moral values-most obviously laws against killing, adultery and false witness, for example. Morality has a wider scope than the law: actions regarded as immoral are not necessarily illegal. However, in societies with some separation between the sacred and the secular, the law alone would be inadequate to maintain the cohesion of society: moral prescriptions are essential (Devlin 1958).

Early in human history, morality was probably concerned only with issues of fairly direct relevance to individual survival and reproduction. As societies became more complex its scope became wider. The same is probably true of law, which became necessary through the need for formalization and for stronger means to control severe infringements. Thus, the range of actions that can be regarded as moral/ immoral is broader than those considered as legal/illegal. Occasionally, both the law and morality are concerned with behaviour that lies at the extremity of behaviour that is otherwise condoned or normal, such as marital rape.

Law has been shaped by moral values, and laws that do not have some reference to social values are seldom viable. However, a few laws and moral precepts are constructed by influential individuals, either for what they perceive as the good of the community or for their own interests. While morality prescribes how people should behave, most laws are concerned with how people ought not to behave.

Moral precepts are not to be seen as absolutes. They are neither ubiquitous and unchangeable, nor are they entirely culture-specific. They are based on and constrained by pancultural propensities (to behave prosocially to kin and to others perceived as in-group members and, in some cases, to further one's own interests). In a given society at a given time, they may be seen as absolutes. The law, like morality, has a certain lability, though it is seen as absolute at any one time. Scientific innovations pose new problems: changes over such issues as abortion and paid egg sharing demand legal solutions.

Some rules of conduct and some laws are concerned not so much with what is seen as right as with ensuring the smooth running of society. Thus some psychologists argue for a distinction between morals and conventions, supposing that they depend on distinct conceptual domains (Turiel 1998). Justifications for judgements about morality include promoting welfare, justice, rights, truth, loyalty, etc., whereas conventions involve merely understanding the social organization. In the same way, some laws have a clear relationship to moral principles (e.g. laws relating to murder) and others merely reify conventions (e.g. driving on the left-hand side of the road). However, the distinctions are often far from clear, and both may be seen as promoting social cohesion or the welfare of the community.

Morals are often seen as based on divine or other undefined authority, and the viability of moral precepts in a world devoid of religious believers and a religious tradition remains to be seen. Laws are based ultimately on secular authority.

Morality is absorbed through experience into the selfsystems of individuals. So-called moral intuition is not something with which humans are endowed, but is acquired in the culture in question. Law, by definition, has been imposed. Moral behaviour may be either automatic, constrained by precepts incorporated in the self-system, or intentional. Intentionality is therefore a less salient characteristic in judgements of morality than in many judgements of legal guilt.

The effectiveness of public morality is maintained by guilt processes within the individual, by social disapproval and by fear of punishment in this life or the next. Laws stipulate how (within limits) offenders should be treated.

In democracies, most law has been formulated in the interests of the society as a whole or of most individuals within it. As the example of the Israeli kibbutzim suggests, in practice the common good requires a legal system as well as moral precepts to restrict the activities of free riders. In some cases, for instance in wartime, law is imposed for the public good but against the wishes of the majority. Occasionally, as in the case of apartheid in South Africa, it is imposed against both the interests and the wishes of the majority.

So-called 'Natural Law' holds that there are objective moral principles that depend on the nature of the universe and can be discovered by reason. Although I have argued that morality is based on human nature, what is natural is not necessarily the same as what is right. Ultimately, basic principles are pancultural not because they are self-evident or accord with common practice nor because they are divinely inspired, but because individuals do better in groups.

The perceived validity of moral principles depends ultimately on their acceptance by individuals. No distinction can be made between the moral opinions of the collective and 'truth', though individuals may hold idiosyncratic moral opinions. Law, to be viable in a reasonably democratic society, must be perceived as compatible with the generally received morality (Warnock 1998). In practice, changes in the law tend to be influenced more by the morality of the élite than that of the population as a whole. Thus in the UK, the legal status of homosexual 
relationships was changed largely through the influence of the more educated minority.

The principle of prosocial reciprocity provides a basis for most moral precepts concerned with personal relationships or relations with the community. Reciprocity and commitment (see $\S 2$ c) also provide a basis for many laws (e.g. contract law; Goodenough 2001). It also contributes to the determination of punishments, though group coherence may demand (also) an additional penalty.

Some philosophers (e.g. Bentham) have held that no rights exist unless they are encapsulated in the law. However, in modern legal systems the law is usually based on perceived human rights, not vice versa, and rights have become a moral matter, and not mere social conventions. There is a danger in this, for individual rights must be curtailed for the good of others.

There may be moral limits to requirements to obey or not to obey the law (Devlin 1965). Similarly 'human rights' cannot be claimed by every individual, and may be limited by other aspects of the common good.

Although there is bound to be a broad resemblance between the law and morality, the coincidence is not absolute. Some acts now considered as immoral, such as slavery, have been seen as legal. Many laws prescribe behaviour that is morally neutral, such as the side of the road on which one should drive - though it must be noted that the aim of such laws is the common good. Some laws, like some moral precepts, are related to the well-being of the lawmakers or of a section of society, rather than to the common good.

Legal theory often depends on contrasting principles, such as equality, utilitarianism or justice. Most though not all moral principles are reducible to a variant of the Golden Rule (do-as-you-would-be-done-by), though that is open to different interpretations. In the historical genesis of morality, equality, utilitarianism and justice, though not unimportant, were secondary considerations, probably depending on which was most conducive to group integrity in the circumstances prevailing.

In dividing resources, neither morality nor the law provides clear guidance on the detailed principles (e.g. equality, equity, need, utilitarianism) to be followed. The first three are most likely to satisfy those immediately involved, but utilitarian distribution may favour the coherence of the group.

'The law' has usually been codified within societies and applied primarily to in-group members. However, the basic principles of selfish assertiveness and prosociality apply also to societies as entities themselves. That implies a need to frame or to re-frame laws to govern the relations between societies. Not only is it morally repulsive that vast inequalities of opportunity exist between individuals, but also between countries. The use of or threat to use nuclear weapons and other weapons of mass destruction, and even war itself, are morally unacceptable and contrary to the basic principle of prosociality: international law must not only outlaw them but also be enforceable.

The author is grateful to Lord Mustill PC, for his comments on an earlier draft.

\section{ENDNOTES}

1 The argument given here involves a summary of that given previously in Hinde (1999) and more especially Hinde (2002). The present paper contains only the outlines of the argument and the more essential references: greater detail is to be found in the latter book.

2 'Prosocial' is used as a blanket term to cover diverse types of behaviour that foster the well-being of others.

3 'Assertiveness' has positive connotations for some, negative for others. It is used here to refer to behaviours that promote one's own interests without regard for the interests of others, i.e. selfish assertiveness.

\section{REFERENCES}

Adams, H. 1896 Essays on Anglo-Saxon law. Boston, MA: Little Brown.

Alexander, R. D. 1979 Darwinism and human affairs. Seattle, WA: University of Washington Press.

Arnhart, L. 1998 Darwinian natural right: the biological ethics of human nature. Albany, NY: State University of New York Press.

Backman, C. W. 1988 The self: a dialectical approach. Adv. Exp. Soc. Psychol. 21, 229-260.

Betzig, L., Borgerhoff Mulder, M. \& Turke, P. (eds) 1988 Human reproductive behavior: a Darwinian perspective. Cambridge University Press.

Bevc, I. \& Silverman, I. 2000 Early separation and sibling incest: a test of the revised Westerman theory. Evol. Hum. Behav. 21, 151-161.

Bottéro, J. 1992 Mesopotamia: writing, reasoning and the gods. University of Chicago Press.

Bowlby, J. 1984 Attachment and loss, vol. 1, 2nd edn.London: Hogarth.

Boyd, R. \& Richerson, P. J. 1991 Culture and cooperation. In Cooperation and prosocial behaviour (ed. R. A. Hinde \& J. Groebel), pp. 27-48. Cambridge University Press.

Boyd, R. \& Richerson, P. J. 1992 Punishment allows evolution of cooperation (or anything else) in sizeable groups. Ethol. Sociobiol. 13, 171-195.

Cosmides, L. \& Tooby, J. 1992 Cognitive adaptations for social exchange. In The adapted mind (ed. J. H. Barkow, J. Tooby \& L. Cosmides), pp. 163-228. New York: Oxford University Press.

Daly, M. \& Wilson, M. 1996 Violence against stepchildren. Curr. Dir. Psychol. Sci. 5, 77-81.

De Vries, M. W. 1984 Temperament and infant mortality among the Masai of East Africa. Am. F. Psychiat. 141, 11891194.

Devlin, Lord 1958 Morals and the criminal law. Maccabaean Lecture, British Academy.

Devlin, P. 1965 The enforcement of morals. London: Oxford University Press.

Dworkin, R.M. 1973 The law of the slave catchers. Times Literary Supplement, 5 December, p. 1437.

Eisenberg, N. \& Fabes, R. A. 1998 Prosocial development. In Handbook of child psychology, 5th edn, vol. 3 (ed. W. Damon \& N. Eisenberg), pp. 701-778. New York: Wiley.

Evans-Pritchard, E. E. 1940 The Nuer. Oxford: Clarendon.

Finnis, J. 1980 Natural law and natural rights. Oxford: Clarendon.

Frank, R. H. 1988 Patterns within reason. New York: Norton.

Freeman, M. D. A. (ed.) 2001 Lloyd's introduction to jurisprudence, 7th edn. London: Sweet \& Maxwell.

Gilligan, C. 1982 In a different voice. Cambridge, MA: Harvard University Press.

Goodenough, O. 2001 Law and the biology of commitment. In Evolution and the capacity for commitment (ed. R. M. Nesse), pp. 262-291. New York: Russell Sage.

Grand, J. C. \& Bittles, A. H. 1997 The comparative role of consanguinity in infant and child mortality in Pakistan. Ann. Hum. Genet. 61, 143-149.

Hamilton, W. D. 1964 The genetical evolution of social behaviour. F. Theor. Biol. 7, 1-52. 
Hart, H. L. A. 1994 The concept of law. Oxford: Clarendon.

Hawkes, K., O’Connell, J. F. \& Blurton Jones, N. G. 2001 Hadza meat sharing. Evol. Hum. Behav. 22, 113-142.

Hill, K. \& Hurtado, M. 1996 Aché life history: the ecology and demography of a foraging people. Hawthorne, NY: Aldine de Gruyter.

Himma, K. E. 2003 Trouble in law's empire: rethinking Dworkin's third theory of law. Oxf. F. Legal Stud. 23, 345-377.

Hinde, R. A. 1999 Why gods persist. London: Routledge.

Hinde, R. A. 2002 Why good is good. London: Routledge.

Hrdy, S. 1999 Mother nature. New York: Pantheon.

Hsu, E. 1998 Moso and Naxi: the house. In Naxi and Moso ethnography: kin, rites, pictographs (ed. M. Oppitz \& E. Hsu), pp. 67-99. Zurich: Völkerkundemuseum.

Humphrey, N. 1997 Varieties of altruism-and the common ground between them. Soc. Res. 64, 199-209.

Huntingdon, S. 1997 The West and the rest. Prospect 1997, 34-39.

James, W. 1988 The listening ebony. Oxford: Clarendon.

Jones, O. D. 1997 Evolutionary analysis in law: an introduction and application to child abuse. North Carolina Law Rev. $75,1117-1342$.

Kelley, H. H. 1979 Personal relationships. Hillsdale, NJ: Erlbaum.

Küng, H. \& Kuschel, H.-J. 1993 A global ethic. London: SCM Press.

Prins, K. S., Buunk, B. P. \& van Yperen, N. W. 1993 Equity, normative disapproval, and extramarital relationships. $\mathcal{F}$. Soc. Person. Relation. 10, 39-53.
Rheingold, H. \& Hay, D. 1980 Prosocial behavior of the very young. In Morality as a biological phenomenon (ed. G. S. Stent), pp. 93-108. Berkeley, CA: University of California Press.

Roth, M. T. 1995 Law collections from Mesopotamia and Asia Minor. Atlanta, GA: Scholars' Press.

Saltman, M. 1985 'The law is an ass': an anthropological appraisal. In Reason and morality (ed. I. Overing), pp. 226239. London: Tavistock.

Silk, J. B. 1980 Adoption and kinship in Oceania. Am. Anthropol. 82, 799-820.

Sober, E. \& Wilson, D. S. 1998 Unto others. Cambridge, MA: Harvard University Press.

Tangney, J. P. 1995 Recent advances in the empirical study of shame and guilt. Am. Behav. Sci. 38, 1132-1145.

Thibaut, J. W. \& Kelley, H. H. 1959 The social psychology of groups. New York: Wiley.

Trivers, R. 1974 Parent-infant conflict. Am. Zool. 14, 249264.

Turiel, E. 1998 The development of morality. In Handbook of child development, 5th edn, vol. 3 (ed. W. Damon \& N. Eisenberg), pp. 863-932. New York: Wiley.

Warnock, M. 1998 An intelligent person's guide to ethics. London: Duckworth.

Williams, J. E. \& Best, D. L. 1982 Measuring sex stereotypes. Beverley Hills, CA: Sage.

Wilson, D.S. \& Kniffen, K.M. 1999 Multilevel selection and the social transmission of behavior. Hum. Nature 10, 291-310. 